\title{
Virtual Mouse Berdasarkan Warna RGB Menggunakan Metode Optical Flow Secara Real-Time
}

\author{
Muhammad Hermansyah', Nurul Fadillah² \\ ${ }^{1}$ Program Studi Teknik Informatika, Fakultas Teknik, Universitas Samudra \\ e-mail: moehammadhermansyah@gmail.com \\ ${ }^{2}$ Program Studi Teknik Informatika, Fakultas Teknik, Universitas Samudra \\ e-mail: nurulfadillah@unsam.ac.id
}

Cara Sitasi: Hermansyah, M., \& Fadillah, N. (2019). Virtual Mouse Berdasarkan Warna RGB Menggunakan Metode Optical Flow Secara Real-Time. Paradigma - Jurnal Komputer dan Informatika, 21(2), $249-252$. doi:10.31294/p.v21i2.5258

\begin{abstract}
As technology develops at this time, the method used to enable users to interact with virtual objects must be required to be more natural and intuitive, one example of which is the development of a virtual mouse. Virtual mouse is designed for users to be able to interact directly with computers without using input devices such as conventional mice but using their own hands as driving objects or using other media such as colors as objects. In this research, testing is done on how to track an object that moves in order to do the mouse by using an intermediary in the form of image processing-based webcam video taken in real-time by using tracking objects in the form of three color variables compiled based on RGB composition using the optical flow method in detecting its movements. The results of the research that have been obtained as a whole that the RBG color object used as the cursor controller on the mouse with the optical flow method can be detected properly, the Red color will move the cursor on the mouse, Blue as the left mouse click, and color Green as right-click on the mouse.
\end{abstract}

Keywords: Virtual Mouse, RGB Color, Optical Flow, Webcam

\section{PENDAHULUAN}

Zaman semakin berkembang pesat, begitu pula dengan teknologi dan ilmu pengetahuan yang juga turut berkembang dengan pesatnya. Hal ini, membuat manusia berpikir dan berlomba-lomba untuk mengembangkan teknologi. Manusia mulai memanfaatkan teknologi dan ilmu pengetahuan, dengan membuat aplikasi yang dapat membantu pekerjaannya. Teknologi yang berkembang saat ini, dimanfaatkan mulai dari membantu pekerjaan manusia yang sederhana hingga yang kompleks di segala bidang kehidupan, seperti bisnis, pendidikan, pertanian, penerbangan, dan lain sebagainya.

Seiring dengan perkembangan teknologi, metode yang akan digunakan agar pengguna dapat berinteraksi dengan objek virtual harus dituntut untuk lebih natural dan intuitif karena kebanyakan perangkat keras (hardware) sekarang ini lebih bersifat mekanik seperti mouse, keyboard dan joystick. Oleh karena itu, pendeteksian dengan hand motion tracking diharapkan dapat menghubungkan antara user dan komputer agar lebih interaktif dan dinamis lagi sehingga akan bersifat alami sebagaimana interaksi antar manusia. Dari perkembangan itulah muncul istilah virtual mouse. Virtual Mouse di desain bagi user agar dapat berinteraksi secara langsung dengan komputer tanpa menggunakan input device seperti mouse konvensional tetapi menggunakan tangannya sendiri sebagai objek interaksinya dengan perantara berupa webcam video.

Berdasarkan hal tersebut, maka dalam penelitian ini dilakukan pengembangan sistem agar komputer bisa berinteraksi dengan manusia secara langsung dengan tracking pada suatu objek yang bergerak. Komputer harus terlebih dahulu memahami pola suatu objek tangan sebagai simbol-simbol yang telah ditentukan sehingga dibutuhkan pengolahan citra (image processing) sebagai pembelajaran dan nantinya digunakan sebagai serangkaian informasi bahasa isyarat pengendali mouse secara virtual dan real-time. Dengan demikian diperlukan suatu metode dalam mengidentifikasi pola atau objek tangan untuk mendeteksi dan menghasilkan output sesuai dengan perintah atau informasi yang telah ditentukan. Salah satu metode yang bisa digunakan adalah metode Optical Flow.

Optical Flow adalah perkiraan gerakan suatu bagian dari sebuah citra berdasarkan turunan intensitas cahayanya pada sebuah citra yang dapat mengetahui pergerakan suatu piksel dari frame ke frame berdasarkan nilai intensitas. Penerapan dari metode ini adalah untuk melakukan pelacakan pendeteksian 
gerakan, menghitung kecepatan pergerakan dan keakurasian dalam mendeteksi objek yang bergerak. (Amardip G., Binitha C.. 2015)

\section{A. Computer Vision}

Pengolahan citra adalah pengolahan suatu citra dengan menggunakan komputer, untuk menghasilkan suatu citra yang lain. Hubungan pengolahan citra dengan computer vision yaitu pengolahan citra merupakan proses awal (preprocessing) pada computer vision. Computer vision mencoba meniru cara kerja visual manusia (Human Vision). Human Vision sesungguhnya sangat kompleks, manusia melihat objek dengan indera penglihatan (mata) lalu objek citra diteruskan ke otak untuk diinterpretasi sehingga manusia mengerti objek apa yang tampak dalam pandangan matanya. (Ngurah W., Darma P. 2012)

Computer vision merupakan bagian dari komputer yang menjalankan suatu proses otomatis yang menghubungkan sejumlah besar proses untuk pandangan visual, seperti akuisisi citra, pengolahan citra, klasifikasi, pengenalan (recognition), dan membuat keputusan. Computer vision (visi komputer) terdiri atas teknik-teknik untuk memperkirakan ciri-ciri dan bentuk objek dalam citra, pengukuran ciri yang berkaitan dengan geometri objek dan menginterpretasi informasi geometri citra. Proses-proses dalam computer vision dibagi dalam 3 (tiga) aktivitas :

1. Memperoleh atau mengakuisisi citra digital.

2. Melakukan teknik komputasi untuk memproses dan memodifikasi data citra (operasi-operasi pengolahan citra).

3. Menganalisis dan menginterpretasi citra menggunakan hasil pemrosesan untuk tujuan tertentu, seperti mengontrol robot, mengontrol peralatan dan benda, memantau manufaktur, dan lain-lain.

\section{B. Virtual Mouse}

Virtual Mouse merupakan salah satu bagian augmented reality dan computer vision yang memiliki fungsi untuk melakukan interaksi secara langsung antara manusia dan komputer dengan menggunakan perantara berupa webcam. (Umami R., Irawan H., 2017)

Virtual Mouse juga merupakan teknologi termutakhir untuk interaksi antara manusia dan komputer yang banyak dikembangkan oleh para peneliti saat ini. Seiring dengan perkembangan teknologi, metode yang akan digunakan agar pengguna dapat berinteraksi dengan objek virtual harus dituntut untuk lebih natural dan intuitif. Oleh sebab itu, pendeteksian dengan hand tracking diharapkan dapat menghubungkan antara manusia dan komputer agar lebih interaktif dan dinamis lagi. Dari perkembangan itulah muncul istilah virtual mouse. Virtual Mouse didesain bagi manusia dapat berinteraksi secara langsung dengan komputer tanpa menggunakan input device seperti mouse konvensional tetapi menggunakan tangannya sendiri sebagai objek interaksinya. Terdapat banyak metode untuk melakukan hand tracking diantaranya adalah dengan menggunakan metode Optical Flow. Metode kombinasi antara Optical Flow telah banyak digunakan untuk object tracking dan memiliki tingkat akurasi yang tinggi.

\section{Metode Optical Flow}

Optical Flow adalah perkiraan gerakan suatu bagian dari sebuah citra berdasarkan turunan intensitas cahayanya pada sebuah citra yang dapat mengetahui pergerakan suatu piksel dari frame ke frame berdasarkan nilai intensitas. Optical flow merupakan pola dari pergerakan objek, permukaan, dan sisi pinggir atau ujung yang terlihat dalam sebuah pemandangan visual, yang terjadi karena pergeseran relatif antara pengamat (kamera atau mata) dengan pemandangan yang dilihat. Optical flow ini akan mengingat sebuah gambar piksel di frame pertama, kemudian di frame kedua mencari piksel terdekat dengan kecerahan yang sama. (Umar, dkk. 2011)

\section{Konsep Citra Gray dan Warna}

Warna adalah kesan yang diperoleh mata dari cahaya yang dipantulkan oleh benda-benda yang dikenalinya. Warna yang diperoleh mata dari sebuah objek ditentukan oleh warna sinar yang dipantulkan oleh objek tersebut. Warna-warna yang dapat ditangkap oleh mata manusia merupakan kombinasi cahaya dengan panjang berbeda. Citra grayscale memberi kemungkinan warna yang lebih banyak dari pada citra biner, karena ada nilai-nilai lain diantara nilai minimum (biasanya $=0$ ) dan nilai maksimum. Banyaknya kemungkinan minimum dan nilai maksimumnya bergantung pada jumlah bit yang digunakan. (Konstyono, Hariz N. 2015)

Citra Gray merupakan warna-warna piksel yang berada pada rentang warna hitam dan putih. Jumlah warna pada citra gray adalah 256 , karena citra gray jumlah bitnya adalah 8 , sehingga jumlah warnanya adalah $28=256$, nilanya berada pada jangkauan 0 255. Sehingga nilai intensitas dari citra gray tidak akan melebihi 255 dan tidak memungkinkan kurang dari 0. Sedangkan jumlah warna untuk citra RGB (Red, Green, Blue) adalah dengan mengalikan jumlah pada masing-masing komponennya, jumlah dari tiap komponennya, $\mathrm{R}=255$ ( 8 bit) $\mathrm{G}=255$ ( 8 bit) dan $\mathrm{B}=255(8$ bit) sehingga sering kali disebut citra dengan intensitas 24 bit.

\section{E. Webcam}

Webcam (kamera web) adalah sebutan bagi kamera waktu nyata yang gambarnya bisa dilihat melalui www (World Wide Web), program pengolah pesan cepat, atau aplikasi pemanggilan video. Umumnya istilah webcam merujuk pada teknologi, sehingga kata webcam kadang diganti dengan kata lain yang memberikan pemandangan yang ditampilkan di 
kamera. Kamera web dapat diartikan juga sebagai sebuah kamera video digital kecil yang dihubungkan ke komputer melalui port USB, port COM atau dengan jaringan Ethernet atau Wi-Fi. Fungsi dari webcam telah kita ketahui yaitu untuk memudahkan kita dalam mengolah pesan cepat seperti chat melalui video atau bertatap muka melalui video secara langsung. Selain itu webcam juga berfungsi sebagai alat untuk mentransfer sebuah media secara langsung, namun perlu diketahui kebanyakan pengguna menggunakan piranti ini hanya untuk chat video. (Umar, dkk. 2011)

Sebuah webcam (kamera web) sederhana terdiri dari sebuah lensa standar yang dihubungkan pada sebuah papan sirkuit untuk menangkap sinyal gambar, casing atau pelindung, termasuk casing depan dan casing samping untuk menutupi lensa standar dan memiliki sebuah lubang lensa di casing depan yang berfungsi untuk menginputkan gambar, kabel support yang dibuat dari bahan yang fleksibel, salah satu ujungnya dihubungkan dengan papan sirkuit dan ujung satu lagi memiliki connector (penghubung), kabel ini dikontrol untuk menyesuaikan ketinggian, arah dan sudut pandang kamera web. Biasanya webcam dilengkapi dengan perangkat lunak (software), perangkat lunak (software) ini mengambil gambar dari kamera digital secara terus menerus atau dalam interval waktu tertentu dan menyiarkannya melalui koneksi internet. Ada beberapa metode penyiaran, metode yang paling umum adalah hardware mengubah gambar ke dalam bentuk file JPG dan menguploadnya ke web server menggunakan File Transfer Protocol (FTP).

Frame rate mengindikasikan jumlah gambar sebuah software (perangkat lunak) dapat ambil dan transfer dalam satu detik. Untuk streaming video diperlukan minimal 15 frame per second (fps) atau idealnya 30 fps. Untuk mendapatkan frame rate yang tinggi, dibutuhkan koneksi internet yang cepat dan stabil. Sebuah kamera web tidak harus selalu terhubung dengan komputer, ada kamera web yang memiliki software webcam dan web server bulit-in, sehingga yang diperlukan hanyalah koneksi internet. Kamera web seperti ini dinamakan network camera. Pengguna bisa menghindari pemakaian kabel dengan menggunakan hubungan radio, koneksi Ethernet ataupun Wi-Fi. Pada perancangan aplikasi webcam untuk digunakan pada mikroskop digital, webcam akan dihubungkan ke PC atau komputer untuk menampilkan hasil gambar yang terlihat. Untuk mengatur pencahayaan dan fokus, webcam tersebut dibantu oleh Arduino Uno. Webcam berguna sebagai lensa yang dipakai pada mikroskop digital. (Umar, dkk. 2011)

\section{METODOLOGI PENELITIAN}

Metode penelitian ini secara garis besar digambarkan pada gambar 2.1. Metodologi penelitian merupakan cara yang digunakan untuk melakukan pengamatan dengan pemikiran yang tepat secara terpadu melalui tahapan-tahapan yang disusun secara ilmiah untuk mencari, menyusun serta menganalisis dan menyimpulkan data, sehingga dapat dipergunakan untuk menemukan, mengembangkan dan menguji kebenaran sesuai ilmu pengetahuan.

Metodologi penelitian merupakan cara yang digunakan untuk melakukan pengamatan dengan pemikiran yang tepat secara terpadu melalui tahapantahapan yang disusun secara ilmiah untuk mencari, menyusun serta menganalisis dan menyimpulkan data, sehingga dapat dipergunakan untuk menemukan, mengembangkan dan menguji kebenaran sesuai ilmu pengetahuan.

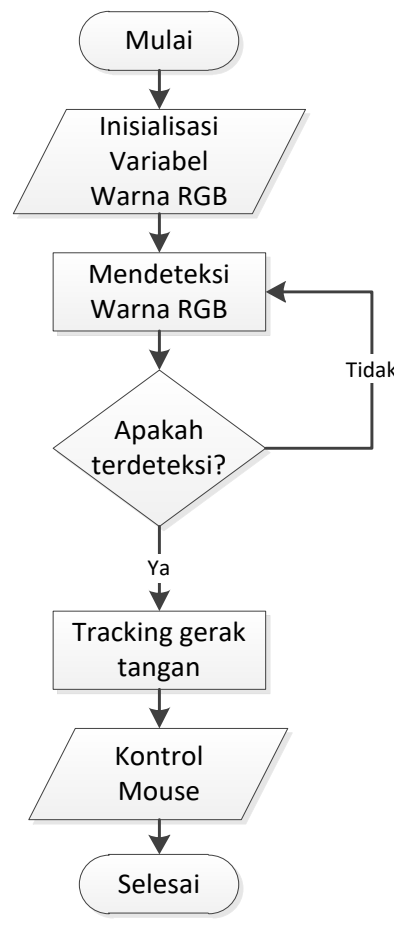

Gambar 2.1 Flowchart Deteksi Warna RGB Pada Virtual Mouse

\section{A. Inisialiasi Variabel Warna RGB}

Warna RGB merupakan citra yang tersusun oleh tiga kanal warna yaitu kanal merah, kanal hijau, dan kanal biru. Pada citra RGB 24 bit, masing-masing setiap kanal warna memiliki nilai intensitas piksel dengan kedalaman bit sebesar 8 bit yang artinya memiliki variasi warna sebanyak $2^{8}=256$ derajat warna (0 sampai dengan 255). Setiap pixel pada citra RGB memiliki nilai intensitas yang merupakan kombinasi dari nilai R, G, dan B. Variasi warna pada setiap pixel pada citra RGB adalah sebanyak $256 *$ $256 * 256=16.777 .216$.

\section{B. Mendeteksi Warna RGB}

Mendeteksi warna RGB merupakan proses dari menganalisis nilai warna dari tiap piksel pada citra dan membagi citra tersebut sesuai dengan fitur yang diinginkan. Warna yang diambil adalah warna dengan 
komposisi RGB (Red, Green, Blue) setelah itu deteksi warna digunakan unruk memisahkan mana warna RGB dan mana yang bukan.

\section{Tracking Gerak Tangan}

Setelah dilakukan mendeteksi warna RGB kemudian dilakukan tracking gerak tangan terhadap objek warna tersebut menggunakan metode optical flow dalam pendeteksian pergerakannya dan kemudian barulah digunakan perintah mouse.

\section{Kontrol Mouse}

Kontrol Mouse merupakan cara untuk mengendalikan mouse dengan ujung jari pada virtual panel yang dapat kita capai agar lebih akurat dan efektif dalam berinteraksi dengan komputer bahkan dengan jarak yang lebih besar atau lebih jauh dari jarak kamera.

\section{HASIL DAN PEMBAHASAN}

Hasil yang akan ditampilkan pada penelitian ini yaitu terdapat 3 buah objek warna dengan masing-masing warna akan terdeteksi oleh webcam. Warna tersebut diantaranya adalah warna RGB (Red, Green, Blue) yang dimana setiap warna memiliki fungsi, antara lain:

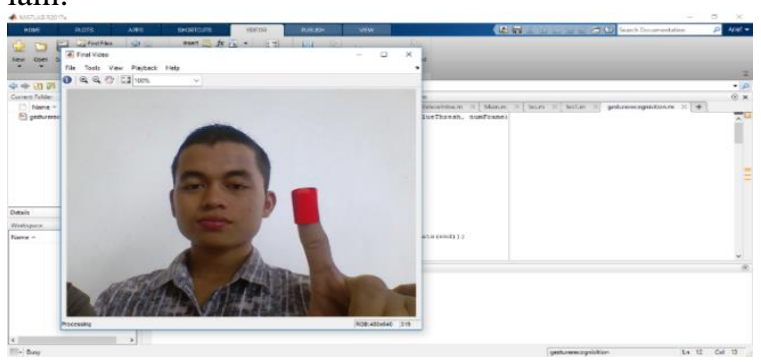

Gambar 3.1 Deteksi Warna Merah (Red)

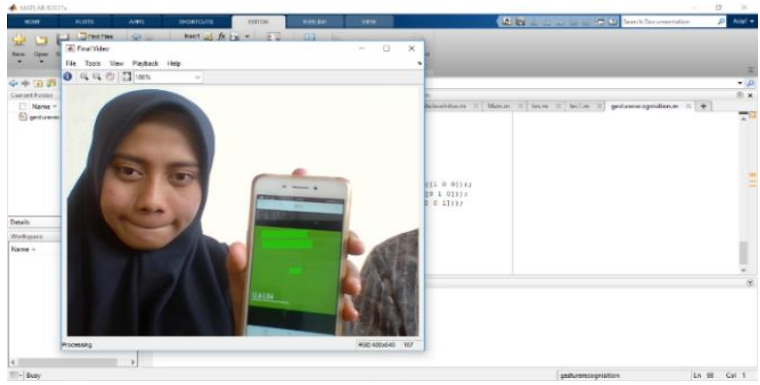

Gambar 3.2 Deteksi Warna Hijau (Green)

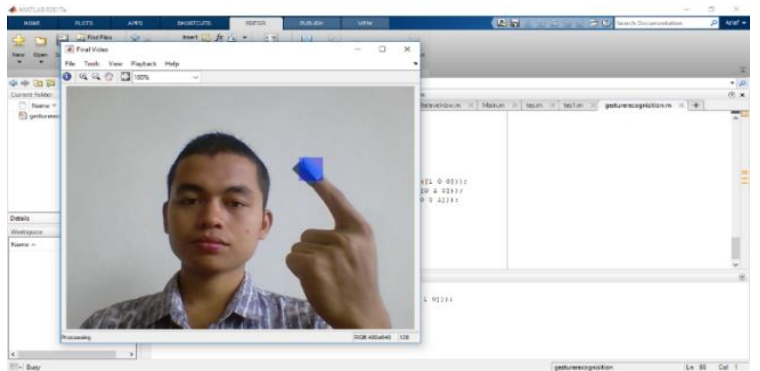

Gambar 3.3 Deteksi Warna Biru (Blue)
Setelah dilakukan pengujian dengan warna RGB yang digunakan, maka didapatkan hasil yaitu :

1. Red (Merah) berfungsi sebagai penggerak kursor pada mouse.

2. Green (Hijau) berfungsi sebagai klik kanan pada mouse.

3. Blue (Biru) berfungsi sebagai klik kiri pada mouse.

\section{KESIMPULAN}

Berdasarkan penelitian yang telah dilakukakan maka dapat disimpulakn bahwa warna yang disusun berdasarkan komposisi RGB dapat digunakan sebagai objek virtual dalam mengendalikan pointer atau mouse. Dimana setiap kondisi terdapat warnawarna yang lebih mudah terdeteksi seperti warna merah, warna hijau, dan warna biru. Percobaan ini telah berhasil mendeteksi warna RGB dan tracking objek secara real time dengan menggunakan metode optical flow yang di pakai pada percobaan sebelumnya.

\section{REFERENSI}

Amardip G., Binitha C.. (2015). Virtual Mouse Using Hand Gesture and Color Detection. Government College of Engineering. India.

Konstyono, Hariz N. (2015). Hand Tracking Menggunakan Metode Lucas Kanade Dan Kalman Filter Pada Virtual Mouse. Teknik Telekomunikasi, Fakultas Teknik Elektro, Universitas Telkom.

Ngurah W., Darma P. (2012). Mouse Virtual Dengan Objek Tracking Jari Tangan Manusia. Teknologi Informasi, Universitas Udayana, Bali.

Umami R., Irawan H., (2017). Penerapan Hand Motion Tracking Pengendali Pointer Pada Virtual Mouse Dengan Metode Optical Flow. Teknik Elektro, Politeknik Negeri Sriwijaya, Palembang.

Umar, dkk. (2011). Tracking Arah Gerak telunjuk Jari Berbasis Webcam Menggunakan Metode Optical Flow. Bandung. 